\title{
Nitrogen Balance of Starting Barrow Pigs Fed on Increasing Lysine Levels
}

\author{
Ivan Moreira*, Alessandro Luis Fraga, Diovani Paiano, Gisele Cristina de Oliveira, \\ Cláudio Scapinello and Elias Nunes Martins \\ Departamento de Zootecnia; Universidade Estadual de Maringá; imoreira@ uem.br; Av. Colombo, 5.790; Zona 07; \\ 87.020-900; Maringá - PR - Brazil
}

\begin{abstract}
The effects of increasing lysine levels on nitrogen balance of pigs fed on low protein diets were evaluated. Four treatments (diets) containing lysine levels (0.8, 1.01 .2 and 1.4\%) were applied to 12 starting (20.0 $\pm 1.8 \mathrm{~kg})$ barrow pigs. Methionine, threonine and tryptophan were kept constant to the lysine ratio in all diets. Feces and urine were collected during a 5-day period. Nitrogen output in urine (NOU), total nitrogen output (TNO), nitrogen retention (NR), net protein utilization (NPU), biological value or feed protein (BVFP), urine urea nitrogen (UUN), and plasma urea nitrogen (PUN) were determined. PUN showed high negative correlations with BVFP (-0.84), $N P U(-0.76)$, and NR (-0.78) and a positive correlation (0.79) to NOU. Lowest nitrogen excretion and the best use of diet protein were obtained with $1.1 \%$ total lysine level. PUN is efficient to indicate amino acid for pigs.
\end{abstract}

Key words: Environmental pollution, crystalline amino acids, protein metabolism, slurry

\section{INTRODUCTION}

Pig production has an important role on the supply of safe meat for people. However, safety in pig production has meant environmental security coupled to a reduction in excretion elements, such as nitrogen (Oliveira, 2001). Nitrogen excretion is determined by certain factors, mainly crude protein content of diet. The use of low protein in pig diets supplemented with amino acid reduces nitrogen excretion, without any decrease in performance (Canh et al., 1998). Amino acids are required by pigs within a constant profile expressing the amino acid to lysine ratio in an ideal protein concept (Baker, 1996). When the lysine requirement is determined, other amino acids requirements may be easily calculated.
Lysine requirement of pigs is influenced by factors such as gender, body weight, genetics and temperature (Miyada, 1996). Nitrogen balance trials are not only used to determine amino acid requirement for pigs (Lewis and Nishimura, 1995), but also for the best amino acid ratio (Hahn and Baker, 1995). They determine nitrogen excretion and retention caused by different amino acid levels in experimental diets.

This study investigated the effect of increasing lysine levels on nitrogen balance of starting barrow pigs fed on diets formulated according to the ideal protein concept. Lysine level that results in the best use of diet protein and lowest nitrogen excretion was also determined.

\footnotetext{
* Author for correspondence
} 


\section{MATERIALS AND METHODS}

A nitrogen balance trial was carried out with 12 crossbred barrow pigs (Large-White $\mathrm{x}$ Landrace/Large-White) from dam line SEGHERS $^{\circledR}$, selected for high lean contents. Barrows $(20.0 \pm 1.8 \mathrm{~kg} \mathrm{BW})$ were randomly assigned to individual steel metabolism cages, equipped with stainless steel feeders and plastic floors. Average room temperature during the trial ranged between $22.8 \pm 1.0^{\circ} \mathrm{C}$ (minimum) and 29.2 $\pm 2.4^{\circ} \mathrm{C}$ (maximum).

Treatments consisted of four low-protein diets with increasing lysine levels. A basal diet $(0.8 \%$ total lysine) was formulated with corn-soybean meal. Crystalline amino acids (L-lysine $\mathrm{HCl}$, DLmethionine, L-threonine and L-tryptophan) were added to keep the ideal profile constant, as indicated by NRC (1998). Parameters were barrow pigs, $22.5 \mathrm{~kg}$ body weight with $300 \mathrm{~g}$ daily lean gain and 3,400 Kcal digestible energy/ $\mathrm{kg}$ diet. The other three diets $(1.0,1.2$ and $1.4 \%$ total lysine) were formulated by supplementing the basal diet with crystalline amino acids (L-lysine $\mathrm{HCl}$, DL-methionine, L-threonine and Ltryptophan) at the expense of cornstarch. Thus, the ideal amino acids profile (considering lysine, methionine+cystine, threonine and tryptophan) was maintained constant in all experimental diets adding synthetic amino acid.

Yellow corn and soybean meal were analyzed for crude protein. Amino acid values were obtained from crude protein, according to EMBRAPA (1991) feed composition. Table 1 presents yellow corn and soybean meal compositions. Centesimal, chemical and energetic compositions of experimental diets are shown in Tables 2 and 3.

Pigs were blocked by body weight and allotted to 4 treatments $(0.8,1.0,1.2$ and $1.4 \%$ total lysine $)$ and distributed in three replicates. Pigs were adapted to crates and diets during 7 days (pretreatment period); 5 days of total fecal and urine collection period followed.

The amount of daily fed diet was calculated according to daily feed intake of each pig during the pre-treatment period and metabolic weight $\left(\mathrm{kg}^{0.75}\right)$ of pigs, when body weight at the end of pre-treatment period has been taken into account.

Barrows were fed twice a day (0800 and 2000) and water was given after each meal at a ratio of 3.0 $\mathrm{mL}$ of water/ $1 \mathrm{~g}$ of diet intake. Ferric oxide $\left(\mathrm{Fe}_{2} \mathrm{O}_{3}\right)$ was used as an indigestible marker to indicate the beginning and the end of fecal collection period.

Feces were collected, weighted and frozen daily. Urine was collected continuously over the 5-day collection period through a tulle into a plastic bucket containing $10 \mathrm{~mL}$ sulfuric acid as preservative. Urine volume was measured and recorded daily and a $20 \%$ aliquot was retained and stored. All samples were stored at $-18^{\circ} \mathrm{C}$ until analysis. Prior to analyses, feces were thawed and mixed thoroughly. Feces sample was dried at $65^{\circ} \mathrm{C}$, ground through a $1 \mathrm{~mm}$ screen and then stored until laboratory analysis. Urine samples were thawed and strained through a coffee filter prior to nitrogen analysis. Nitrogen content of diets, feces and urine samples was analyzed by Kjeldahl procedure (AOAC, 1975).

Table 1 - Crude protein ${ }^{1}$ and amino acids ${ }^{2}$ composition (as-fed basis) of yellow corn and soybean meal used in experimental diets ${ }^{1}$

\begin{tabular}{lcc}
\multicolumn{1}{c|}{ Nutrient } & Yellow corn & Soybean meal \\
\hline Crude protein ${ }^{2}, \%$ & 9.40 & 44.39 \\
Lysine, $\%$ & 0.260 & 2.623 \\
Methionine + cystine, \% & 0.357 & 1.069 \\
Threonine, \% & 0.292 & 1.584 \\
Tryptophan, \% & 0.065 & 0.733 \\
\hline
\end{tabular}

Analyzed by Animal Nutrition Laboratory;

${ }^{2}$ Based on EMBRAPA (1991) amino acids values. 
Table 2 - Percentage composition of experimental diets (as-fed basis)

\begin{tabular}{|c|c|c|c|c|}
\hline \multirow{2}{*}{ Ingredients, \% } & \multicolumn{4}{|c|}{ Total lysine levels, \% } \\
\hline & 0.8 & 1.0 & 1.2 & 1.4 \\
\hline Yellow corn & 81.04 & 81.04 & 81.04 & 81.04 \\
\hline Soybean meal & 12.60 & 12.60 & 12.60 & 12.60 \\
\hline Soybean oil & 1.19 & 1.19 & 1.19 & 1.19 \\
\hline Dicalcium phosphate & 1.44 & 1.44 & 1.44 & 1.44 \\
\hline Limestone & 0.74 & 0.74 & 0.74 & 0.74 \\
\hline Common salt & 0.40 & 0.40 & 0.40 & 0.40 \\
\hline Vitamin-mineral mix ${ }^{1}$ & 0.50 & 0.50 & 0.50 & 0.50 \\
\hline Antibiotic (Tylan S 100) & 0.10 & 0.10 & 0.10 & 0.10 \\
\hline Corn starch & 1.70 & 1.16 & 0.62 & 0.09 \\
\hline L-lysine $\mathrm{HCl}(78,8 \%)$ & 0.180 & 0.434 & 0.688 & 0.942 \\
\hline DL- methionine (99\%) & 0.029 & 0.143 & 0.258 & 0.372 \\
\hline L- threonine (98\%) & 0.082 & 0.215 & 0.347 & 0.478 \\
\hline L-tryptophan (98\%) & 0.000 & 0.038 & 0.074 & 0.112 \\
\hline
\end{tabular}

Table 3 - Chemical and energetic composition of experimental diets

\begin{tabular}{l|c|c|c|c}
\hline \multirow{2}{*}{ Nutrients } & \multicolumn{4}{c}{ Total lysine levels, \% } \\
\cline { 2 - 5 } & 0.8 & 1.0 & 1.2 & 1.4 \\
\hline Digestible energy, kcal/kg & 3,400 & 3,408 & 3,416 & 3,424 \\
Crude protein, \% & 13.61 & 14.04 & 14.46 & 14.89 \\
Calcium, \% & 0.65 & 0.65 & 0.65 & 0.65 \\
Total phosphorus, \% & 0.55 & 0.55 & 0.55 & 0.55 \\
Na + K - Cl 1, meq/kg & 130.1 & 116.0 & 102.2 & 1.4 \\
Lysine, \% & 0.8 & 1.0 & 1.2 & 0.792 \\
Methionine + cystine, \% & 0.453 & 0.566 & 0.679 & 0.905 \\
Threonine, \% & 0.517 & 0.647 & 0.776 & 0.255 \\
Tryptophan, \% & 0.145 & 0.182 & 0.218 & \\
\hline
\end{tabular}

${ }^{\mathrm{T}}$ Values calculated based on Mogin and Sauveur (1977) and compositions of feed indicated by Rostagno et al. (2000).

The values of nitrogen intake (NI), output in feces (NOF) and in urine (NOU) were calculated by multiplying nitrogen levels of diets, feces and urine, by feed intake, excreted feces and urine, respectively. Nitrogen absorption $(\mathrm{NAB}=\mathrm{NI}-$ $\mathrm{NOF})$, total output $(\mathrm{TNO}=\mathrm{NOF}+\mathrm{NOU})$, retention $(\mathrm{NR}=\mathrm{NI}-\mathrm{TNO})$, net protein utilization $(\mathrm{NPU}=\mathrm{NR} / \mathrm{NI})$ and the biologic value of feed protein $(\mathrm{BVFP}=\mathrm{NR} / \mathrm{NAB})$ were subsequently calculated according to Adeola (2001).

Blood samples were obtained (1330) at start and end of trial. Blood (approximately $8 \mathrm{ml}$ ) was collect by anterior vena cava puncture in heparinized tubes. Plasma urea nitrogen (PUN) and UUN concentrations were determined by enzymatic method using Ecoline Kit 25 $\left(\right.$ MERCK $\left.^{\circledR}\right)$. PUN and UUN values were calculated by multiplying the results (in $\mathrm{mg} / \mathrm{dL}$ of urea) by 0.467 , or rather, the nitrogen content of urea molecule (Newman and Price, 1999). Initial PUN (pre-treatment period) was used as a covariate to correct final PUN (treatment period) for individual animals differences, as suggested by Coma et al. (1995b).

Data were submitted to polynomial regression analysis, according to the following statistic model:

$\mathrm{Y}_{i j}=\mu+\mathrm{b}_{1}\left(\mathrm{~N}_{j}-\mathrm{N}\right)+\mathrm{b}_{2}\left(\mathrm{~N}_{j}-\mathrm{N}\right)^{2}+e_{i j}$, where:

$\mathrm{Y}_{i j}=$ recorded value of variables, referring to each $k$ pig, fed $j$ lysine level;

$\mu=$ general constant;

$\mathrm{b}_{1}=$ linear regression coefficient of lysine level on variable Y; 
$\mathrm{b}_{2}=$ quadratic regression coefficient of lysine level on variable $\mathrm{Y}$;

$\mathrm{N}_{j}=$ lysine levels in the experimental diets, with $j$ $=0.8 ; 1.0 ; 1.2$ e $1.4 \%$;

$\mathrm{N}=$ average lysine level (1.1\%) in the experimental diets;

$e_{i j}=$ error for each record.

Feed intake (FI) was used as covariate to NI, NOF, NOU and UUN. Values in each pig (replicate) were corrected to average feed intake (AFI) of total pigs by equation: $\mathrm{CV}_{j}=\mathrm{OV}_{j}-\mathrm{b}_{1}$ (AFI OFIj), where: $\mathrm{CV}$ was the corrected value of variable response to FI in $j$ pig; OV was the observed value of variable response in $j$ pig; $b_{1}$ was the linear regression coefficient of FI, and OFI was the feed intake in $j$ pig. Quadratic equations were derived to estimate lysine level, which resulted in the best response.

\section{RESULTS AND DISCUSSION}

Laboratory analyses for protein content of experimental diets were $13.39,13.66,13.94$ and $14.44 \%$, corresponding respectively to $0.8,1.0,1.2$ and $1.4 \%$ total lysine diets. Data from nitrogen balance and plasma urea nitrogen are shown in
Table 4. Table 5 shows quadratic equations for each variable.

The amount of feed given to the pigs was determined according to their feed intake during the adaptation period and their body weight, so, there were differences among their feed intake, but not differences among treatments. Increasing lysine levels led to increasing NI, which was not reported by Coelho et al. (1987). Reduction in urinary nitrogen excretion meant reduction in urea excretion from amino acid catabolism. Lysine level that brought about minimum UUN (1.10\%) was thus similar to minimum NOU (1.10) and TNO (1.09). Their equations were similar too. NPU represents NR:NI ratio and BVFP the NR:NAB ratio (Adeola, 2001). Since there was a similar increase in NAB and NI, it was expected that the best lysine values for NPU should be close to BVFP. Actually, these values $(1.12 \%)$ were identical in our trial. The correlation coefficients between variables are shown in Table 6. High negative correlation between PUN and NR (Table 6), was likewise reported by Coma et al. (1995a). Since, a very high correlation between PUN and NOU was observed, we concluded that PUN was useful, easy and a fast way to indicate urinary nitrogen excretion in pigs. However, optimum lysine levels for PUN and NOU were different (1.15 and $1.10 \%$, respectively).

Table 4 - Feed intake (FI), nitrogen intake (NI), nitrogen output in feces (NOF), nitrogen absorption (NAB), nitrogen output in urine (NOU), total nitrogen output (TNO), nitrogen retention (NR), net protein utilization (NPU), biological value or feed protein (BVFP), urine urea nitrogen (UUN) and plasma urea nitrogen (PUN) of pigs fed at increasing lysine levels

\begin{tabular}{|c|c|c|c|c|c|c|c|}
\hline \multirow{2}{*}{ Variable $^{1}$} & \multicolumn{4}{|c|}{ Total lysine levels, \% } & \multirow{2}{*}{$\mathrm{CV}, \%$} & \multirow{2}{*}{ Effect } & \multirow{2}{*}{$\mathbf{P}$} \\
\hline & $\mathbf{0 , 8}$ & 1,0 & 1,2 & 1,4 & & & \\
\hline FI, g/d & 927 & 950 & 914 & 934 & 14,2 & - & $>0,1$ \\
\hline NI, g/d & 19.6 & 19.9 & 20.4 & 21.1 & 0.49 & Linear & $<0,01$ \\
\hline $\mathrm{NOF}, \mathrm{g} / \mathrm{d}$ & 2.45 & 3.15 & 2.52 & 2.84 & 12.3 & - & $>0,1$ \\
\hline $\mathrm{NAB}, \mathrm{g} / \mathrm{d}$ & 17.1 & 16.8 & 17.8 & 18.3 & 1.9 & Linear & $<0,01$ \\
\hline NOU, g/d & 4.26 & 2.63 & 3.09 & 4.15 & 9.5 & Quadratic & $<0,01$ \\
\hline TNO, g/d & 6.71 & 5.79 & 5.60 & 6.99 & 5.9 & Quadratic & $<0,01$ \\
\hline $\mathrm{NR}, \mathrm{g} / \mathrm{d}$ & 12.9 & 14.2 & 14.8 & 14.1 & 2.7 & Quadratic & $<0,01$ \\
\hline NPU, \% & 65.7 & 71.0 & 72.5 & 66.9 & 2.4 & Quadratic & $<0,01$ \\
\hline BVFP, \% & 75.1 & 84.3 & 82.7 & 77.3 & 2.2 & Quadratic & $<0,01$ \\
\hline UUN, g/d & 3.20 & 1.65 & 2.13 & 3.18 & 14.4 & Quadratic & $<0,01$ \\
\hline PUN, mg/dL & 8.09 & 3.97 & 3.97 & 5.76 & 21.9 & Quadratic & $<0,05$ \\
\hline
\end{tabular}

Values were corrected for feed intake, except PUN. 
The quadratic response of nitrogen urinary excretion (Table 4) might have been caused either by maximum lysine utilization capacity of pigs reached within the studied range (around 1.1\% total lysine) or by ideal lysine: energy ratio of the total lysine level above. However, experimental diets (Table 3) contained very low crude protein, with a highest reduction than the limit indicated by Kendall et al. (1998). In this case, the high crude protein reduction might have become valine, a limiting amino acid (Mavromichalis et al., 1998). Consequently, the quadratic response of nitrogen urinary excretion might have been caused by optimum amino acid balance obtained at approximately $1.1 \%$ total lysine (valine to lysine ratio). In instances with over $1.1 \%$ total lysine, all amino acids added exceeded valine content, being thus degraded and their nitrogen excreted.

Table 5 - Equations and estimated best lysine levels to nitrogen output urine (NOU), total nitrogen output (TNO), nitrogen retention (NR), net protein utilization (NPU), biologic value of feed protein (BVFP), and urine (UUN) and plasma urea nitrogen (PUN) of pigs fed on increasing lysine levels

\begin{tabular}{lcccccc}
\hline \multicolumn{1}{c}{ Variable } & $\mathbf{b}_{\mathbf{0}}$ & $\mathbf{b}_{\mathbf{1}}$ & $\mathbf{b}_{\mathbf{2}}$ & $\mathbf{R}^{\mathbf{2}}$ & $\mathbf{R M S}^{\mathbf{1}}$ & Best lysine level, \% $^{\mathbf{2}}$ \\
\hline NOU & 23.06 & -37.02 & 16.82 & 85.2 & .104 & 1.10 \\
TNO & 22.64 & -31.45 & 14.47 & 78.6 & .123 & 1.09 \\
NR & 2.597 & 29.04 & 12.20 & 85.9 & .116 & 1.19 \\
NPU & -12.73 & 152.5 & 68.21 & 79.6 & .744 & 1.12 \\
BVFP & -29.40 & 204.1 & -91.50 & 86.3 & .023 & 1.12 \\
UUN & 20.30 & -35.73 & 16.30 & 79.9 & .147 & 1.10 \\
PUN & 52.32 & -84.96 & 36.97 & 72.2 & .274 & 1.15 \\
\hline
\end{tabular}

${ }^{\mathrm{T}}$ Residual mean square.

Table 6 - Correlation coefficient between plasma urea nitrogen (PUN) and nitrogen output urine (NOU), urine urea nitrogen (UUN), biological value of feed protein (BVFP), net protein utilization (NPU) and nitrogen retention (NR)

\begin{tabular}{lcc}
\hline Variables & Correlation & P \\
\hline PUN vs NOU & 0.79 & $<0.005$ \\
PUN vs UUN & 0.74 & $<0.01$ \\
PUN vs BVFP & -0.84 & $<0.005$ \\
PUN vs NPU & -0.76 & $<0.01$ \\
PUN vs NR & -0.78 & $<0.005$ \\
\hline
\end{tabular}

Although the highest NR represented the highest protein deposition and the optimum lysine level to NR was next to optimum level in pig weight gain (Coma et al., 1995a), the importance of nitrogen excretion reduction by the pig production systems and the cost of protein feed may indicate more interesting variables with better nitrogen utilization (NPU and BVFP). Thus, in this trial $1.1 \%$ was accounted as the best total lysine level for pigs fed on low crude protein diets (around $14.2 \%$ crude protein). In physiological conditions, PUN is the resultant catabolism from excess of amino acids in the pig utilization capacity, or unbalanced amino acids beyond the protein turnover that normally occurs in animals (Lehninger, 1993). PUN indicates the urea (nitrogen) production at a specific moment, while NOU and UUN are the nitrogen production during the 5-day period. Consequently differences between PUN and NOU and UUN equations have been reported. However, these equations also showed similar best lysine levels. The best lysine level indicated by PUN (1.15\%) was intermediary among those indicated by other variables. Since PUN had a high correlation between some variables, it was efficient to indicate the utilization of pig amino acids it has thus been concluded that PUN could be a valid variable to establish pig amino acid requirement, as cited by Chen et al. (1995).

FI did not influence PUN $(>0.1)$; and then PUN values were not corrected to FI. Initial PUN (baseline) was determined to be a covariate in the PUN analysis (Coma et al., (1995b). However, there was no effect $(\mathrm{P}>0.01)$ of baseline on PUN and thus the baseline was not included in the 
statistic model. Average baseline value was 13.4 $\mathrm{mg} / \mathrm{dL}$ when pigs were fed on a $19 \%$ crude protein content diet (commercial starting pig diet); average PUN value (when pigs fed on low crude protein content diets) was $5.5 \mathrm{mg} / \mathrm{dL}$. In this case, diets formulated according to ideal protein concept caused a 59\% $(\mathrm{P}<0.01)$ reduction on PUN, which indicated a great reduction in nitrogen urinary excretion. Cahn et al (1998) reported a $45 \%$ reduction on nitrogen urinary excretion when crude protein content diet decreased from 16.5 to $12.5 \%$. The average ratio of NR to NC amounted to $69 \%$, in fact higher than the 30 to $40 \%$ that generally occurs (Oliveira, 2001).

Results indicated that pigs fed on low crude protein content diet adjusted for amino acid requirements, showed low nitrogen excretion. They, therefore, reduced their potential on environmental pollution. Starting barrow pigs showed the best use of dietary protein and the lowest nitrogen excretion at $1.1 \%$ total lysine content in low crude protein diets (14.2\%) formulated according to ideal protein concept.

\section{AKNOWLEDGEMENT}

The authors would like to thank AJINOMOTO BIOLATINA for supplying the amino acids; to RAÇALTO BRASIL AGROPECUÁRIA for providing the animals; to Ms. Marlene Leiko Doi Sakuno for urea analysis; to CNPq-Brazil for scholarships given to authors.

\section{RESUMO}

Foi realizado um experimento para se determinar o efeito de níveis crescentes de lisina sobre o balanço de nitrogênio de suínos, alimentados com rações de baixo teor protéico. Doze suínos machos castrados em fase inicial $(20,0 \pm 1,8 \mathrm{~kg})$ foram distribuídos em 4 tratamentos (dietas) com níveis crescentes de lisina total $(08,1,01,2$ e $1,4 \%)$. Os níveis de metionina, treonina e triptofano foram mantidos constantes em relação à lisina. Foram coletadas fezes e urina durante o período de cinco dias. Foram determinados os nitrogênios excretados na urina (NEU), total excretado (NTE), retido (NR), a utilização líquida da proteína (ULP), o valor biológico da proteína dietética (VBPD), o nitrogênio da uréia plasmática (NUP) e urinária (NUU). O NUP foi altamente correlacionado com o VBPD $(-0,84)$, ULP $(-0,76)$, NEU $(0,79)$ e NR (-0,78). O melhor aproveitamento da proteína dietética e a menor excreção de nitrogênio foram obtidos com $1,1 \%$ de lisina total. O NUP é eficiente para indicar a utilização de aminoácidos pelos suínos.

\section{REFERENCES}

Adeola, O. (2001), Digestion and balance techniques in pigs. In: Lewis, A. J. and Southern, L. L. (Eds.). Swine Nutrition. Boca Raton : CRC Press. pp. 917960.

Baker, D. H. (1996), Advances in amino acid nutrition and metabolism of swine and poultry. In: Kornegay, E. T. (Ed.). Nutrient Management of Food Animals to Enhance and Protect the Environment. Boca Raton : CRC Press. pp. 41-53.

Cahn, T. T.; Aarnink, A. J. A. and Schutte, J. B. et al. (1998), Dietary protein affects nitrogen excretion and ammonia emission from slurry of growing-finishing pigs. Livest. Prod. Sci., 56, 181-191.

Coelho, L. S. S.; Costa, P. M. A. nad Silva, M. A. et al. (1987), Exigência de lisina de suínos de 15 a $30 \mathrm{~kg}$ de peso vivo em rações de baixo nível protéico. Rev. Bras. Zootec., 16, 60-71.

Chen, H. Y.; Miller, P. S. and Lewis, A. J. et al. (1995), Changes in plasma urea concentration can be used to determine protein requirements of two populations of pigs different protein accretion rates. J. Anim. Sci.,73, 2631-2639.

Coma, J.; Carrion, D. and Zimmerman, D. R. (1995a), Use plasma urea nitrogen as a rapid response criterion to determine the lysine requirement of pigs. J. Anim. Sci., 73, 472-481.

Coma, J.; Zimmerman, D. R. and Carrion, D. (1995b), Relationship of rate of lean tissue growth and other factors to concentration of urea in plasma of pigs. J. Anim. Sci., 73, 3649-3656.

Empresa Brasileira de Pesquisas Agropecuárias EMBRAPA (1991), Tabela de Composição Química e Valores Energéticos de Alimentos para Suínos e Aves. EMBRAPA/CNPSA, Concórdia.

Hahn, J. D. and Baker, D. H. (1995), Optimum ratio to lysine of threonine, tryptophan and sulfur amino acids for finishing swine. J. Anim. Sci., 73, 482-489.

Kendall, D. C.; Lemenager, K. M. and Richert, B. T. et al. (1998), Effects of Intact Protein Diets Versus Reduced Crude Protein Diets Supplemented with Synthetic Amino Acids on Pig Performance and Ammonia Levels in Swine Buildings. Disponível na Internet: http://www.ansc.purdue.edu/swine/swine day/sday98/psd20-98.htm. 
Lehninger, A. L.; Nelson, D. L. and Michael, M. C. (1993), Amino acid oxidation and the production of urea. In: Lehninger, A. L.; Nelson, D. L. and Michael, M. C. (Ed.). Principles of Biochemistry. New York : Worth publishers. pp. 479-505.

Lewis, A. J. and Nishimura, N. (1995), Valine requirement of the finishing pig. J. Anim. Sci., 73, 2315-2318.

Mavromichalis, I.; Webel, D. M. and Emmert, J. L. et al. (1998), Limiting order of amino acids in a lowprotein corn-soybean meal-whey-based diet for nursery pigs. J. Anim. Sci., 76, 2833-2837.

Miyada, V. S. (1996), Fatores que influenciam as exigências nutricionais dos suínos. In: Paper presented at International Symposium on Nutritional Requirements of Poultry and Swine, 24-26 September. Viçosa, Minas Gerais.

Mongin, P. and Sauveur, B. (1977), Interrelationship between mineral nutrition, acid-base balance, growth and cartilage abnormalities. In: Boorman, K. N. and Wilson, B. J. (Eds.). Growth and Poultry Meat Production. Edinburgh : Br. Poultry Science. pp. 235247.
National Research Council - NRC (1998), Nutrients Requirements of Swine. NRC, Washington.

Newman, D .J. and Price, C. P. (1999), Renal function and nitrogen metabolites. In: Burtis, C. A.; Ashwood, E. R. and Saunders, W. B. Tietz Textbook of Clinical Chemistry. Company, Philadelphia. pp. 1204-1270.

Oliveira, P. A. V. (2001), Produção e Manejo de Dejetos de Suínos. In: Mattos, W. R. S. (Ed.). A Produção Animal na Visão dos Brasileiros. Piracicaba : FEALQ. pp.164-177.

Rostagno, H. S.; Albino, L. F. T. and Donzele, J. L. et al. (2000), Tabelas Brasileiras para Aves $e$ Suínos - Composição de Alimentos e Exigências Nutricionais. Imprensa Universitária/UFV, Viçosa. Silva, D. J. (1990). Análise de Alimentos (Métodos Químicos e Biológicos). Imprensa Universitária/UFV, Viçosa. 